\title{
DETERMINATION OF REASONS AFFECTING THE USE OF INTERNET BANKING THROUGH LOGISTIC REGRESSION ANALYSIS
}

\author{
Ali KÖSE \\ Marmara University, Turkey
}

\begin{abstract}
The most of banks offer almost all of the their products with internet banking by free or very low cost. Althought use of internet banking serves low cost and easy accessible it has been still at very low level. In this article, it was studied that determined causes affecting the use of internet banking on operation of customer who transacts with banks. Therefore it was applied a questionnaire to 300 bank customers about internet banking. And then it was applied logistic regression method to survey data. As a result, in using internet banking has been observed to be effective in internet existence and security as well as income.
\end{abstract}

Keywords: Internet Banking, Banking Customer, Logistic Regression,

\section{INTRODUCTION}

Trade between people and countries started to change dimensions as well together with the technological developments occurred. Important developments in this respect gained speed with the electronic commerce. Although the electronic commerce was being carried out for a long period of time, it became much more facilitated as a result of the spread in internet activities as well as the improvements in information technologies. Enterprises and individuals who would like to make most out of cost and competition related advantages provided by the electronic commerce continue their activities on this subject at an accelerated pace.

Developments at the electronic commerce had also resulted in changes in the banking sector. Banks are always searching for the ways to maximize their profits at minimum costs. And, they can make it in the short run by not opening new branches undertaking risks of high costs, but through products they can generate at less costs in service sectors. Opportunities like accessing accounts at any time required and carrying out operations at lower costs are provided for customers through internet banking while lower costs are offered also for the banks themselves.

In this study, a questionnaire related to internet banking has been applied to 300 bank customers. It has been determined if internet banking is used from the data derived from the questionnaire while the reasons affecting it have also been examined with the method of logistic regression analysis. It has been determined as a result of the study in question that factors like access to the internet, security related issues and ease of communication as well as the income level are influencing the use of internet banking. 


\section{INTERNET BANKING}

Banking operations have been much more facilitated today subject to the developments in technology and new channels for maximization of the profit have appeared owing to the minimization of costs and time risks. One of those important channels is the internet banking.

Internet banking is a system which provides banking services over the internet without any need of place and time (Timur, 2006;22).

Developments in the informatics technology have created new opportunities for the banking sector. Banks then started to provide their ATM, phone banking and internet banking services respectively in line with the developments in technology.

Internet banking system has attracted the attention of the banks in a very short period of time and became an advanced banking element in the field of competition between the banks. Willing to provide easier and faster services to their customers, banks are making profits as well in this way while presenting their services over the internet.

Internet banking has appeared towards the end of especially 1990s. And, banks started to provide their customers the chance of accessing their accounts in the internet environment by making use of various systems of security in the process of development. A bank's customer is able to access to his accounts in a secure manner using the security systems available and carry out almost all of the required operations by himself in a secure internet environment established between him and the bank (Timur, 2006;22).

Internet banking has become an attractive method for banks to be used in the field of obtaining market related information, delivering banking services to its customers in a quick way and increasing its services to its customers.

For the banks there are disadvantages incorporated in internet banking as well besides its advantages. Especially the branchless banking service has advantages like fast 24-hour service, low cost, competitiveness and gaining new customers while the most important disadvantage incorporated in that is its high initial cost.

On the other hand, banks are not able to make profits from internet banking operations for a long period of time after its implementation under intensive conditions of competition available in the market today.

But, banks will undergo a decrease in their competitive powers in the sector if they will not make that investment. Provision of security, confidentiality and social confidence plays an important role in the success of the internet banking which has a wider use among younger population equipped with higher levels of education and grown hand to hand with the technology.

Internet banking has provided some advantages also for the customers besides the ones on behalf of the bank itself. Each customer having a computer and an internet connection may carry out all his operations for 7 days a week and 24 hours a day in the internet banking environment with the exception of withdrawing and depositing cash. Customers are having benefits with regard to the comfort and speed as well as the cost aspects of services they purchase when they are making use of the internet banking environment. In addition to that, there are also services like billing and monthly payments provided over the internet. Customers making investments have even the chance of getting 
higher rates than branches when they would like to manage their money in term deposit accounts using internet banking.

As a result of all the above-mentioned, customers gain important advantages with respect to time, cost and comfort related issues when they use the means of ATM, phone and internet banking in their operations without the need for visiting the branch (with the exception of special cases).

But, this service creates disadvantages for some customers besides its advantages provided for many of them. Some customers are not acquainted with computers while some other are looking at internet banking with suspicious eyes in a fear to have their individual information be stolen by third parties.

Information indicating numbers of customers using the internet banking services and numbers of operations made in this respect for 26 banks providing such services in Turkey with respect to the period 2006-2008 are given in Table 1 and Table 2.

\section{Table 1. Internet Banking Customer Numbers}

\begin{tabular}{|c|c|c|c|c|c|}
\hline Year & Individual & $\begin{array}{c}\text { Individual } \\
(\%)\end{array}$ & Corporate & Corporate (\%) & Total \\
\hline 2006 & 2.803 .482 & 0,88 & 373.222 & 0,12 & 3.176 .704 \\
\hline 2007 & 3.795 .627 & 0,89 & 478.737 & 0,11 & 4.274 .364 \\
\hline 2008 & 4.613 .670 & 0,89 & 555.459 & 0,11 & 5.169 .129 \\
\hline
\end{tabular}

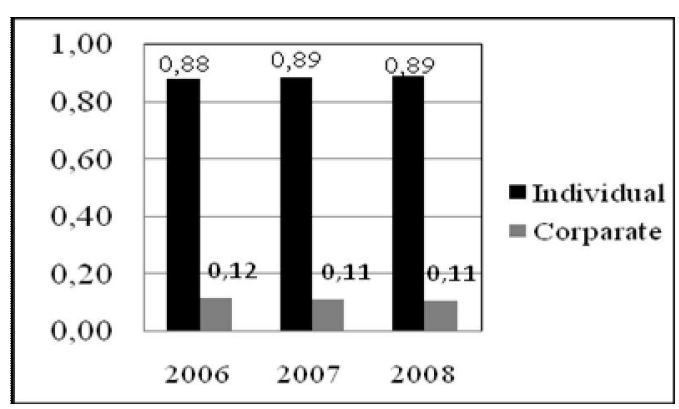

Figure 1. Internet Banking Customer Numbers (\%)

Figure 1. for numbers of customers indicate the number of active customers as of the period 20062008; and, the rate of individual customers using internet banking among the total population of customers utilizing internet banking services has a constant level of $89 \%$ while the rate of corporate customers is $11 \%$ as per the years involved in the study.

Table 2. Internet Operations Numbers

\begin{tabular}{|c|c|c|c|c|c|}
\hline Year & $\begin{array}{c}\text { Non-Financial } \\
\text { Operations* }\end{array}$ & $\begin{array}{c}\text { Non-Financial } \\
\text { Operations (\%) }\end{array}$ & $\begin{array}{c}\text { Financial } \\
\text { Operations }\end{array}$ & $\begin{array}{c}\text { Financial } \\
\text { Operations } \\
(\%)\end{array}$ & Total \\
\hline 2006 & 243.441 & 0,83 & 48.653 & 0,17 & 292.094 \\
\hline 2007 & 150.371 & 0,72 & 58.826 & 0,28 & 209.197 \\
\hline 2008 & 230.428 & 0,77 & 67.190 & 0,23 & 297.618 \\
\hline
\end{tabular}

* Non-financial operations are comprised of the ones like credit card and supplementary card applications, loan applications, regular payment instructions, bill payment instructions and other non-financial operations. 
It is seen when operations over the internet are examined for the specified period that the average rate of non-financial operations is $77 \%$ while the rate of financial operations for the period is at a level like 23\% (Figure 2).

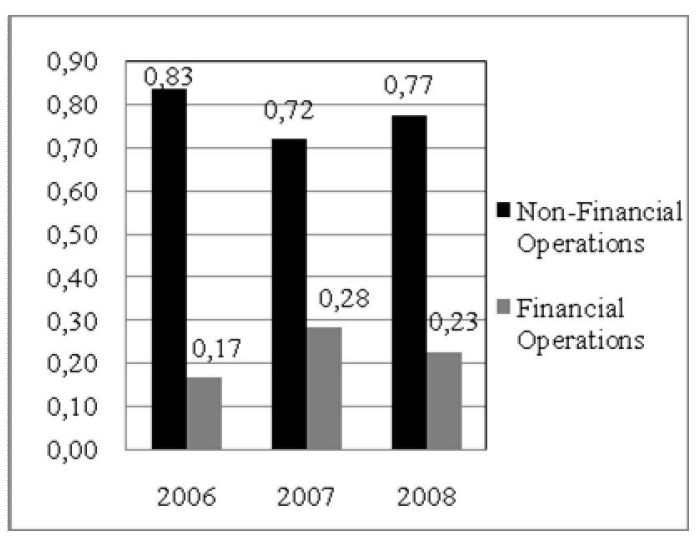

Figure 2. Internet Banking Operation Numbers (\%)

\section{LOGISTIC REGRESSION ANALYSIS}

Multi-variable statistical analysis methods are used very frequently in various sectors like education, health and finance and provide important contributions in obtaining research findings. Incorporating purposes like reduction in dimensions, determination of relations and classification together with various assumptions (like normality, common covariance, etc.) in general; methods of multi-variable statistical analysis provide basically the interpretation and implementation of research result.

Three of the methods used in the classification of observations in groups are the cluster, discriminant and logistic regression analyses. Number of clusters to which observations are to be assigned is unknown in cluster analysis while number of groups (clusters) are known in discriminant and logistic analyses; and, a discrimination model is obtained by making use of the data available and the assignment of new observations added to the cluster of data to groups becomes possible with the help of this model established. The discriminant analysis taking place among models mentioned above is the well-known and most frequently used one and it incorporates heavier assumptions. Logistic regression, on the other hand, is a model started to be frequently used in recent years. This method becomes an alternative to the discriminant analysis and crosstabs in cases of various deformations in assumptions (like normality and having common covariances); and, it provides an ease of use in the case the dependent variable is discrete variable including binary (like 0,1 ) or more than two category (polychotomous) as it does not incorporate the normality assumption. Furthermore, the flexibility and easily interpretable nature of the model, in mathematical point of view, obtained from the analysis increases the interest to this method (Tatlidil, 1992; 225).

Logistic regression analysis is an extension to the multi-regression analysis technique in cases where the dependent variable is categorical. Logistic conversion is the natural algorithm of the rates of success and failure odds. Taking into consideration the logistic conversion of success state probability (p) as a correlation function within the framework of a generalized linear model, $\mathrm{X}_{\mathrm{i}}$ 's express the independent variables and logistic model is obtained as shown below (Oğuzlar, 2005;22).

$\operatorname{Ln}\left(\frac{P}{1-P}\right)=Z=\sum_{k=0}^{P} \beta_{k} X_{k}$ 
When the test, generally the Wald test, for the parameters of the logistic model is evaluated, the ChiSquare test is used for the model which is based on the method of maximum likelihood principle in order to test if the data are well represented in the theoretical model; in other words, to determine the model's suitability for the purpose (Altaş, Giray, 2005; 19, Bircan, 2004; 190, Ege, Bayrakdaroğlu, 2007; 8, Oğuzlar, 2005; 23).

After tests made for model parameters, goodness-for-fit test is assessed for purposes of determining the model to explain the dependent variable in the best way possible. The Hosmer-Lemeshow test is used for testing the goodness for fit. In the next stage, the model's strength to explain is determined using the Nagelkerke $\mathrm{R}^{2}$ statistics and interpretations of parameters obtained through logistic regression analysis are made in the last stage by evaluating the correct percentage of classification (Kalayci, 2005; 292).

\section{LITERATURE}

Adaptation of customers to the system is more important in the widespread use of the internet banking than adaptation of banks to this system. Studies made recently in this subject started to get concentrated more on customers in this subject while researchers in many studies carried out in the past were more involved in the bank related issues.

According to a study made by Sciglimpaqlia and Ely (2002), there were questions comprising of demographic characteristics like gender, age, income status and educational status as well as the issues like transfer costs, bill payments and credit activities asked in the questionnaire which were sent by mail to customers of six branches. Chi-square and probit model has been used for questionnaire analyses. Findings of the study has shown that $32.9 \%$ of customers was preferring to use internet banking due to its time saving nature while banks were losing their customers as they are making their operations through internet banking.

In the survey made by Usta (2005) on the reasons for consumers not using internet banking through a questionnaire form sent to mail addresses of 5000 individuals; demographic variables like genders, ages, monthly incomes and marital and educational statuses have been examined besides other variables like not being aware of benefits from internet banking, operation costs and the resistance to change as well as the difficulties of using it, lack of access to computers and the internet, lack of need to use it and negligence to subscribe. Questionnaires have been analyzed in accordance with the chi-square independence test and consumers believing that internet banking is insecure have taken the first rank in the classification.

Broderick and Vachirapornpuk (2002), on the other hand, have made a research study about the customer's role on the service quality in internet banking. The data used in this study were the ones previous used by other researchers and a draft model has been generated by combining elements derived and enlarged from other studies. It has been determined after studies made that there are five basic elements were effective on the service quality perceived. These elements have been determined as the customer's service expectation, the image and prestige of the service organization, service setting screens, real service fulfillment and customer participation.

Eriksoson and Nilsson (2006) have sent survey questions to 9000 bank customers during their survey on the reasons for preferring internet banking among the self service technologies in use and they have received 1831 replies to their questions. It has been revealed after survey results that the period of use of internet banking and the income levels were effective in using internet banking. 
Korkmaz and Gövdeli (2004), on the other hand, have examined the role of education in the use of alternative distribution channels. Chi-Square and F tests have been used in the study and survey results have revealed that the frequency of bank customers visiting branches were decreased due to the existence of alternative channels, but they were hesitating in using those channels as a result of their insufficient level of knowledge.

The experiences and perceptions of customers with regard to internet banking have been examined in the research study made by Mäenpää, Kale, Kuusela and Mesiranta (2008) in which they have studied users' experiences depending on the increase in the use of internet banking worldwide actively in a fast pace. The study has been implemented in a survey carried out in Finland with the participation of 300 persons using internet banking actively and useful information has been collected with regard to the development of internet banking services as well as the marketing strategies for internet banking. The adoption of low-cost strategies in internet banking services for customers using investment services have been suggested in the study while it has also been stated that there is a need for implementation of more attractive strategies when it comes to younger customers as well as the ones with lower income levels.

\section{ANALYSIS}

A survey covering 300 bank customers has been conducted in the first stage of implementation where they are asked if they are using internet banking and reasons incorporated thereof. Taking into consideration the data obtained in the survey conducted for purposes of determining those reasons, the logistic regression analysis has been used to specify positive and negative reasons influencing the internet banking. According to the findings obtained in the survey, variables affecting the internet banking have been determined as the income status, access to the internet available in the house or workplace, ease of communication, reliability issues and difficulties in the access.

Examining the Omnibus values testing the significance of variables taking place in the model in the initial stage of logistic regression (Table 3), it has been determined that it is a suitable model obtained in the sixth step having a significance of $5 \%$.

Table 3. Omnibus Tests of Model Coefficients

\begin{tabular}{|l|c|c|c|c|}
\hline & & $\begin{array}{c}\text { Chi- } \\
\text { Square }\end{array}$ & df & Sig. \\
\hline \multirow{3}{*}{ Step 6 } & Step & 9,381 & 1 & 0,002 \\
\cline { 2 - 5 } & Block & 193,851 & 6 & 0 \\
\cline { 2 - 5 } & Model & 193,851 & 6 & 0 \\
\hline
\end{tabular}

The Hosmer-Lemeshow test has been applied to determine the goodness for fit in the model and results shown in Table 5 have been reached as a measure of the said model's effectiveness. It has been decided that the model is compatible with the data in consideration of the $\mathrm{H}_{0}$ hypothesis stating that there is no lack of compatibility in the model according to the results obtained.

Table 4. Model Summary

\begin{tabular}{|c|c|}
\hline -2loglikelihood & 202,572 \\
\hline Nagelkerke $^{2}$ & 0,649 \\
\hline
\end{tabular}


Table 5. Test of Hosmer-Lemeshow

\begin{tabular}{|l|c|c|c|}
\hline & $\begin{array}{c}\text { Chi- } \\
\text { Square }\end{array}$ & df & Sig. \\
\hline Step 1 & 79,290 & 2 & 0,000 \\
\hline Step 2 & 76,993 & 5 & 0,000 \\
\hline Step 3 & 31,708 & 8 & 0,000 \\
\hline Step 4 & 10,887 & 7 & 0,144 \\
\hline Step 5 & 11,129 & 8 & 0,194 \\
\hline Step 6 & 9,728 & 8 & 0,285 \\
\hline
\end{tabular}

Looking at the relation between dependent and independent variables taking place in the model, it is observed that the existing variables explain $64.9 \%$ of the relationship (Table 4). According to the results obtained, accurate classification rate of the model has been determined as $86,4 \%$ at the end of the sixth step (Table 6).

Table 6. Classification Table

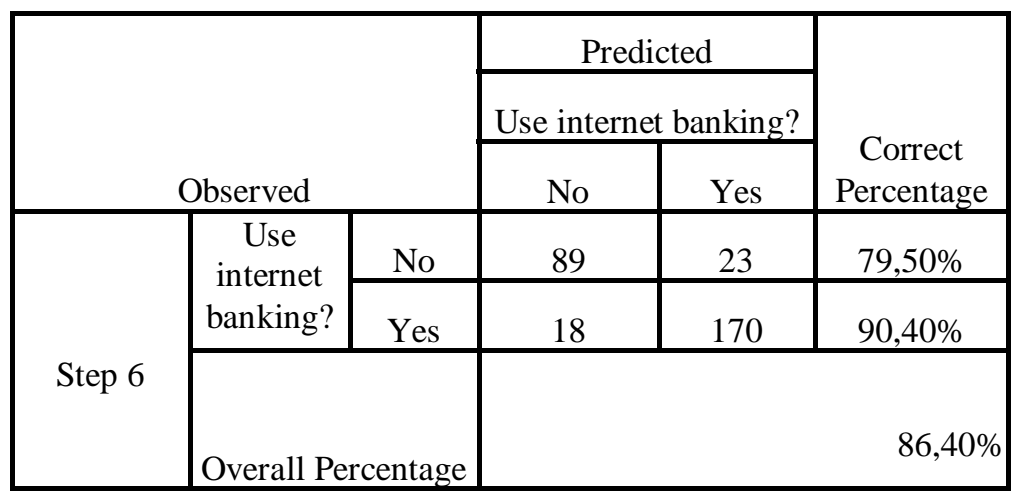

On the other hand, looking at Table 7 where coefficients and significance levels of variables taking place in the model, in this respect is decided that 6 variables taking place in the logistic regression model are statistically significant in accordance with the Wald test. In this case, the logistic regression model obtained in the sixth and last step is established as follows taking into account the data given in Table 7.

$\mathrm{L}=\ln (\mathrm{P} /(1-\mathrm{P}))=2,760+0,863 \mathrm{X}_{\mathrm{IL}}-1,137 \mathrm{X}_{\mathrm{IAH}}-1,976 \mathrm{X}_{\mathrm{IAW}}+0,842 \mathrm{X}_{\mathrm{EC}}-0,535 \mathrm{X}_{\mathrm{II}}-0,582 \mathrm{X}_{\mathrm{DAI}}$

or

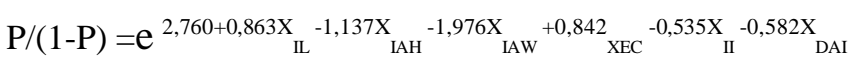

$\mathrm{X}_{\mathrm{IL}}$ : Income Level

$\mathrm{X}_{\mathrm{IAH}}$ : Internet Access at Home

$\mathrm{X}_{\mathrm{IAW}}$ : Internet Access at the Workplace

$\mathrm{X}_{\mathrm{EC}}$ : Ease of Communication

$\mathrm{X}_{\mathrm{II}}$ : Insecurity over the Internet

$\mathrm{X}_{\mathrm{DAI}}$ : Difficulty in Access to Internet 
Looking at $\operatorname{Exp}(B)$ values shown in Table 7, it has been observed that one unit of increase in the income and communication variables causes increases of 2.370 and 2.322 units respectively in the rate of superiority while variables related to access to internet at home/workplace, insecurity and difficulty of access to internet result in decreases like $0.321,0.139,0.586$ and 0.559 respectively in the rate of superiority.

\section{Table 7. Statistics of Model Variables}

\begin{tabular}{|c|c|c|c|c|c|c|c|}
\hline \multirow{4}{*}{} & Variables & $\beta$ & SE & Wald & df & Sig. & $\operatorname{Exp}(\beta)$ \\
\hline \multirow{5}{*}{ Step 6 } & $\mathrm{X}_{\mathrm{GD}}$ & 0,863 & 0,236 & 13,367 & 1 & 0 & 2,37 \\
\cline { 2 - 8 } & $\mathrm{X}_{\mathrm{Ei}}$ & $-1,137$ & 0,375 & 9,211 & 1 & 0,002 & 0,321 \\
\cline { 2 - 8 } & $\mathrm{X}_{\mathrm{Ii}}$ & $-1,976$ & 0,432 & 20,888 & 1 & 0 & 0,139 \\
\cline { 2 - 8 } & $\mathrm{X}_{\mathrm{iL}}$ & 0,842 & 0,203 & 17,18 & 1 & 0 & 2,322 \\
\cline { 2 - 8 } & $\mathrm{X}_{\mathrm{GU}}$ & $-0,535$ & 0,171 & 9,742 & 1 & 0,002 & 0,586 \\
\cline { 2 - 8 } & $\mathrm{X}_{\mathrm{EZ}}$ & $-0,581$ & 0,181 & 10,265 & 1 & 0,001 & 0,559 \\
\cline { 2 - 8 } & Constant & 2,76 & 1,418 & 3,791 & 1 & 0,052 & 15,799 \\
\hline
\end{tabular}

\section{CONCLUSION}

Internet banking has developed in a fast pace and become a channel today where almost all the banks are providing services to their customers.

In this study, 300 bank customers have been asked in a survey first if they are using internet banking and then information has been obtained on the reasons for using or not using such means. Efforts have been spent to find out the reasons affecting the use of internet banking by the implementation of logistic regression technique on the data obtained in the survey.

According to the results of logistic regression model, 6 variables have been found to be statistically significant and the capability of 6 variables in the model to explain the model itself has been found to be around $65 \%$. On the other hand, it has also been determined that the suitable model has accurately classified the data at a high rate like $86,4 \%$.

It has been found out that there are six important factors affecting the use of internet banking at the end of the analysis. Those are; income level, access to internet at home and workplace, ease of communication, insecurity over internet and difficulties in the access.

According to parameter results obtained through the logistic regression model; there is a positive relationship between the income level as well as ease of communication and the rate of superiority. In this case, improvements in the income level and ease of communication result in the increase in the use of internet banking. On the other hand, a negative relation has been determined between other existing variables and the rate of superiority. Thus, improvements in factors like access to internet at home and workplace, insecurity incorporated and difficulties in such access reduce the use of internet banking.

It is estimated that the negative relationship in relation with the access to the internet at home arises from insufficient security in internet connections available at home. There is also a negative relation with regard to the access at workplaces, although it is not at a high level like the access at home. One of the reasons for this is the lack of time due to intensive workloads incorporated at workplaces 
while private works not allowed in working hours as a result of workplace policies may constitute another reason in this respect. It has been observed that the reason for internet banking used at workplaces being in a less negative relationship compared to internet banking operations made at home is arising from the belief that internet security is better at workplaces than connections established at home.

With regard to the insecurity over the internet, on the other hand, adverse opinions of users on internet security reveals the negative relation between the use of internet banking and the insecurity issues although the banks act in a sensitive manner in this subject. Moreover, difficulties experienced by users in accessing the bank's web pages and/or their accounts constitute another factor adversely affecting the use of internet banking.

In the direction of the findings available, banks must give the highest priority to their groups of high income levels in order to increase their internet banking customers while also getting concentrated on providing ease of operations over the web as well as advertisement policies emphasizing the ease of operations in this respect. In addition, they have to develop their security systems related to the access to internet banking continuously in line with the technological innovations and provide the ease of access at the highest level possible at the same time in order to prevent losses in their customers. 


\section{REFERENCES}

Altaş, Dilek and Giray, Selay, (2005), Mali Başarısızlığın Çok Değişkenli İstatistiksel Yöntemlerle Belirlenmesi: Tekstil Sektörü Örneği, Anadolu Üniversitesi, Sosyal Bilimler Dergisi, 5(2), pp.13-27.

Bircan, Hüdaverdi, (2004), Lojistik Regresyon Analizi: Tıp Verileri Üzerine Bir Uygulama, Kocaeli Üniversitesi, Sosyal Bilimler Enstitüsü Dergisi, 2, pp. 185-208.

Broderick, A. J., and Vachirapornpuk, S., (2008), Trans: Dörtyol, T., İnternet Bankacıllı̆ı̆nda Hizmet Kalitesi: Müşteri Rolünün Önemi, C.Ü. İktisadi ve İdari Bilimler Dergisi, 9(1), pp. 131-147.

Ege, İlhan and Bayrakdaroğlu, Ali, (2007), Küreselleşme Sürecinde İMKB Şirketlerinin Hisse Senedi Getiri Başarılarının Lojistik Regresyon Tekniği ile Analizi, 8. Türkiye Ekonometri ve İstatistik Konresi, İnönü Üniversitesi, Malatya, pp. 1-17.

Eriksson, K., and Nilsson, D., (2007), Determinants of the continued use of self-service technology: The case of Internet Banking, Technovation, 27, pp. 159-167.

Kalaycı, Eşref, (2005), SPSS Uygulamalı Çok Değişkenli İstatistik Teknikleri, Asil Yayın Dağııım, Ltd, Şti., Ankara, Türkiye.

Korkmaz, S., and Gövdeli, Y.S., (2005), Türk Bankacılığında Alternatif Dağıtım Kanalları ve Ürünleri İle Bunların Gelişiminde ve Pazarlanmasında Eğitimin Önemi, Endüstriyel sanatlar Eğitim fakültesi Dergisi, 15, pp. 1-12.

Maenpaai K., Kale, H. K., Kuusela, H., and Mesiranta, N., (2008), Consumer perceptions of internet banking in Finland: The moderating role of familiarity, Journal of Retailing and Consumer Services, 15(4) pp. 266-276.

Oğuzlar, Ayşe, (2005), Lojistik Regresyon Analizi Yardımıyla Suçlu Profilinin Belirlenmesi, Atatürk Üniversitesi, İktisadi İdari Bilimler Fakültesi Dergisi, 19(1-2), pp.21-35.

Sciglimpaqlia, D. and Ely, D., (2002), Internet Banking: A Customer-Centric Perspective, 35th Hawaii International Conference on System Sciences, pp.1-10.

Usta, R, (2005), Tüketicilerin İnternet Bankacılı̆̆ını Kullanmama Nedenleri Üzerine

Bir Araştırma, Doğuş Üniversitesi Dergisi, 6(2), pp. 279-290.

Tatlıdil, Hüseyin, (1992), Uygulamalı Çok Değişkenli İstatistiksel Analiz, Cem Web Ofset, Ankara, Türkiye.

Timur, M. N., (2006), Banka ve Sigorta Pazarlaması, Ed.: Odabaşı Y., Anadolu Üniversitesi Yayınları, Yayın No: 1701, Eskişehir, Türkiye.

www.tbb.org.tr 